\title{
Distribution of Heavy Metals, Sulfur and Nitrogen in Thermally Cracked Petroleum Residues Affected by Cracking Severities
}

\author{
Katsutoshi Kikuchi, Koji Ohtsuka, and Koichi Washimi* \\ Toyo Engineering Corporation, 3-2-5 Kasumigaseki, Chiyoda-ku, Tokyo 100
}

(Received March 5, 1986)

\begin{abstract}
Distributions of nickel, vanadium, sulfur and nitrogen in the hexane-soluble and the insoluble fractions in the thermal cracking residue from various heavy petroleum feedstocks have been investigated quantitatively. The thermal cracking reaction was conducted with $1000 \mathrm{ml}$ autoclave at $410^{\circ} \mathrm{C}$ temperature under the pressure of 118 torr. The severity(conversion) of the thermal cracking was varied by adjusting the reaction time. The residue of the cracking was further subjected to solvent fractionation using $n$-hexane as the solvent. The distribution of those elements into the hexane-soluble fraction were correlated with a cracking severity factor, $\mathrm{R} / \mathrm{CCR}_{\mathrm{f}}$, where $\mathrm{R}=$ yield $(\mathrm{wt} \%$ ) of the residue of the thermal cracking on feedstock, and $\mathrm{CCR}_{\mathrm{f}}=$ Conradson carbon residue content of the feedstock. Fairly high correlations were observed when the value of $\mathrm{R} / \mathrm{CCR}_{\mathrm{f}}$ was less than 3 .
\end{abstract}

\section{Introduction}

It has recently been shown that the hetero-cyclic compounds with sulfur, nitrogen, and heavy metals in virgin petroleum are generally concentrated in the heavy fractions ${ }^{1) \sim 4}$, and that the thermal cracking of those heavy fraction further concentrates those compounds by the condensation reaction into the heaviest fraction of the residue of the cracking. ${ }^{5,6)}$ However, no quantitative study has been reported as to the distribution of those compounds or elements in relation to the thermal cracking severity. In the present study, the distribution of those elements from the feedstock into the cracking residue were correlated with a severity factor of the thermal cracking. In order to study the influence of the feedstock characteristics on the distribution, the results with the atmospheric and vacuum residue of various crudes, including Iranian-heavy, Oman (Middle-East), Romashikino (U. S. S. R.), Maya (Mexico), Cerro-Negro, Tia Juana (Venezuela) and Cold-Lake Oil Sand Bitumen (Canada), were compared.

\section{Experimental Apparatus and Procedures}

A batch type thermal cracking unit as shown in Fig. 1 was used for the thermal cracking. The $1,000 \mathrm{ml}$ autoclave reactor, made of Hastelloy-C, was placed in a molten tin-bath which was externally heated by an electric heater. A vacuum pump

\footnotetext{
* To whom correspondence should be addressed.
}

was provided to maintain the proper reactor pressure lower than atmospheric pressure.

The generated heavy cracked distillate was partially condensed by the first condenser, cooled by circulating hot water. The lighter distillate was further condensed by the second condenser, cooled by cooling water. The total volume of the separated gas was measured by a dry gas meter, and then trapped in a baloon for analyzing the components by gas-chromatography. Five hundred $\mathrm{m} l$ of the feedstock was filled in the autoclave and quickly heated up and maintained at the reaction temperature by the hot tin-bath.

A cracking temperature of $410^{\circ} \mathrm{C}$ was employed throughout this study under the total pressure of 118 torr. The total pressure of the reactor was adjusted to maintain flashing condition at the reaction temperature, for evaporating the cracked distillate boiling under $500^{\circ} \mathrm{C}$. The thermal cracking conversion was varied by adjusting the reaction time.

The reaction was terminated by dismantling the autoclave from the tin-bath and cooling by air-fan. Fifty g. of the solidified cracking residue was pulverized to 60-mesh-pass particles and subjected to solvent extraction by $1,000 \mathrm{~m} l n$-hexane (chemical pure grade) under reflux temperature for $60 \mathrm{~min}$ utes. The insoluble residue was then separated by filtration using a G4-glass filter, and dried in a hot oven. The solvent was evaporated from the filtrate by a vacuum rotary dryer at $150^{\circ} \mathrm{C}$. 


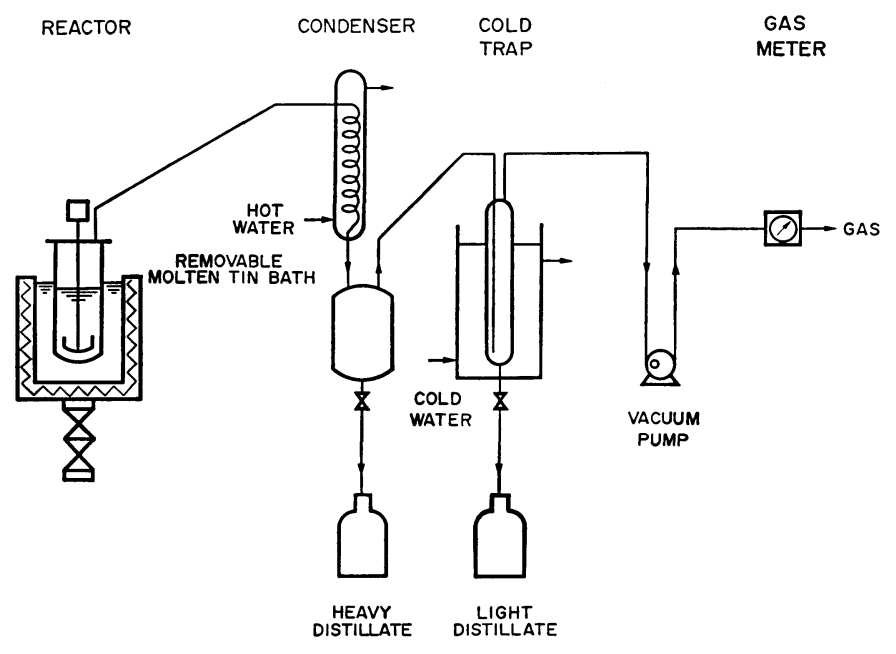

Fig. 1 Thermal Cracking Apparatus

$\mathrm{S}, \mathrm{N}, \mathrm{Ni}$ and $\mathrm{V}$ contents were analyzed from the feedstock, the thermal cracking residue, and the hexane-soluble extract from the cracking residue. Sulfur analysis was made by the bomb method (JIS-K 2541), nitrogen analysis was made by using a Perkin-Elmer Elementary Analyzer $\left(240^{\circ} \mathrm{C}\right)$, nickel analysis was made by atomic absorption spectrophotometry (JPI-55-10-79) and vanadium analysis by a photo absorption method (JPI-55-11-79).

\section{Results and Discussion}

Based on the analysis of sulfur, nitrogen, nickel and vanadium from the feedstock, the cracking residue and the hexane-soluble fraction from the residue, the distribution of each element from the feedstock into the hexane-soluble and the insoluble fractions were calculated (Fig. 2).

The formulas used were: (i) $\mathrm{X} \cdot \mathrm{S}_{\mathbf{x}} / \mathrm{F} \cdot \mathrm{S}_{\mathrm{f}}$, (ii) $\mathrm{X} \cdot \mathrm{N}_{\mathbf{x}} / \mathrm{F} \cdot \mathrm{N}_{\mathrm{f}}, \quad$ (iii) $\mathrm{X} \cdot \mathrm{Ni}_{\mathbf{x}} / \mathrm{F} \cdot \mathrm{Ni}_{\mathrm{f}}, \quad$ (iv) $\mathrm{X} \cdot \mathrm{V}_{\mathbf{x}} / \mathrm{F} \cdot \mathrm{V}_{\mathrm{f}}$, respectively,

Where $\quad \mathrm{X}=\mathrm{R}$ or $\mathrm{E}$ or $\mathrm{A}$ (wt. fraction)

$$
\mathrm{x}=\mathrm{r} \text { or } \mathrm{e} \text { or a (suffix) }
$$

$\mathrm{R}, \mathrm{r}$ : Residue of the thermal cracking $\left(500^{\circ} \mathrm{C}^{+}\right)$

$\mathrm{E}, \mathrm{e}:$ Hexane-soluble fraction in $\mathrm{R}$

A, a : Hexane-insoluble fraction in $R$

F, f : Feedstock

$\mathrm{S}$ : Sulfur content

$\mathrm{N}$ : Nitrogen content

$\mathrm{Ni}$ : Nickel content

$\mathrm{V}$ : Vanadium content

As a normalized measure of the severity of the thermal cracking reaction for various feedstocks, the ratio of $\mathrm{R} / \mathrm{CCR}_{\mathrm{f}}$ was taken, where $\mathrm{CCR}_{\mathrm{f}}$ is the Conradson carbon residue content in the feedstock. $\mathrm{R} / \mathrm{CCR}_{\mathrm{f}}$ value decreases with increasing severity of the thermal cracking and finally ap-

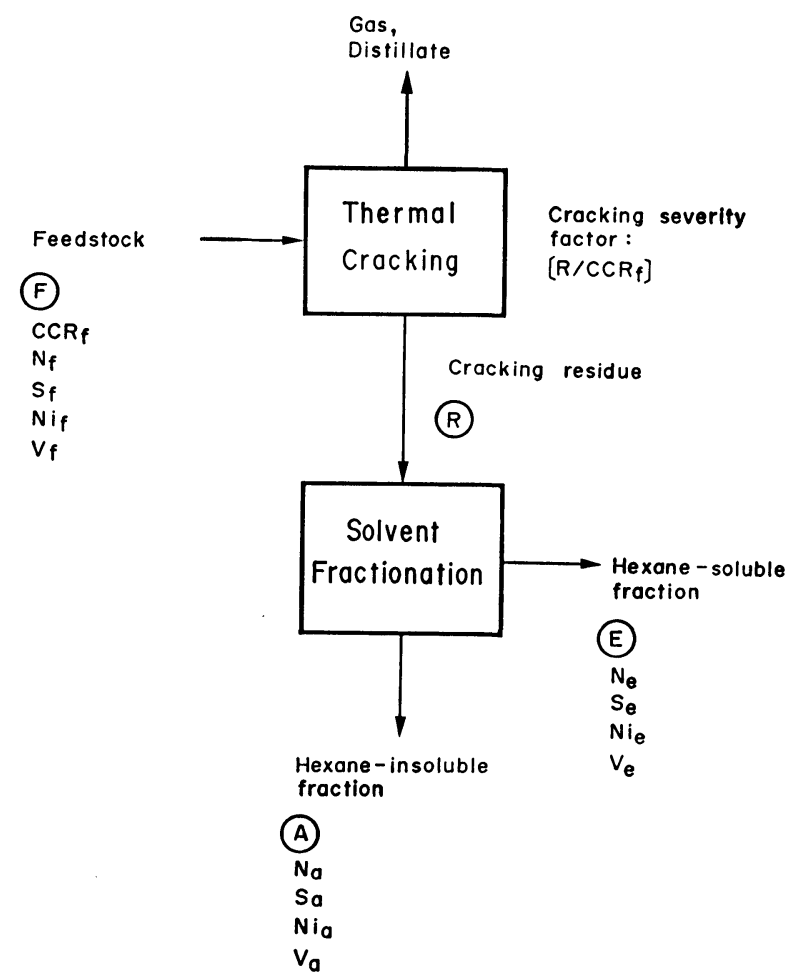

Fig. 2 Procedures of Experiment

proaches to a value close to one. It is well known that in the delayed coking process, the coke yield is nearly proportional to $\mathrm{CCR}_{\mathfrak{f}}$, and the value of $\mathrm{R} / \mathrm{CCR}_{\mathrm{f}}$ is generally about 1.6 .

A part of the analysis data and the calculated values as described above are summarized in Tables 1 and 2.

In Fig. 3, E/R values were plotted against $R /$ $\mathrm{CCR}_{\mathrm{f}}$. The hexane-soluble fraction in the thermal cracking residue decreases with the increase in the thermal cracking severity. This is attributed to 
Table 1 Feedstock Properties, Severity Factors and Distribution of S, N, Ni, V (I)

\begin{tabular}{|c|c|c|c|c|c|c|c|c|c|c|c|c|}
\hline 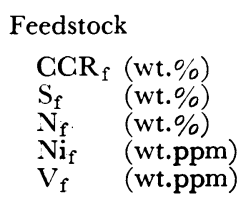 & \multicolumn{4}{|c|}{$\begin{array}{cc}\text { Iranian Heavy } & \text { VR } \\
20.8 & \\
3.8 & \\
0.71 & \\
83 & \\
272 & \end{array}$} & \multicolumn{4}{|c|}{$\begin{array}{c}\text { Cold Lake VR } \\
16.8 \\
5.1 \\
0.56 \\
110 \\
261\end{array}$} & \multicolumn{4}{|c|}{$\begin{array}{c}\text { Romashikino } \\
18.3 \\
3.1 \\
0.86 \\
74 \\
195\end{array}$} \\
\hline $\begin{array}{l}\mathrm{R} / \mathrm{CGR}_{\mathrm{f}} \\
\mathrm{E} / \mathrm{R}\end{array}$ & $\begin{array}{l}4.80 \\
0.90\end{array}$ & $\begin{array}{l}3.13 \\
0.71\end{array}$ & $\begin{array}{l}2.20 \\
0.46\end{array}$ & $\begin{array}{l}1.92 \\
0.39\end{array}$ & $\begin{array}{l}5.95 \\
0.86\end{array}$ & $\begin{array}{l}3.98 \\
0.80\end{array}$ & $\begin{array}{l}3.10 \\
0.68\end{array}$ & $\begin{array}{l}2.01 \\
0.38\end{array}$ & $\begin{array}{l}5.46 \\
0.93\end{array}$ & $\begin{array}{l}3.36 \\
0.75\end{array}$ & $\begin{array}{l}2.11 \\
0.46\end{array}$ & $\begin{array}{l}1.73 \\
0.29\end{array}$ \\
\hline $\begin{array}{cc}\mathrm{S}_{\mathrm{e}} \quad(\mathrm{wt} . \%) \\
\mathrm{N}_{\mathrm{e}} \quad(\mathrm{wt} . \%) \\
\mathrm{Ni}_{\mathrm{e}} \quad(\mathrm{wt} \cdot \mathrm{ppm}) \\
\mathrm{V}_{\mathrm{e}} \quad(\mathrm{wt} \cdot \mathrm{ppm}) \\
\mathrm{E} \cdot \mathrm{S}_{\mathrm{e}} / \mathrm{F} \cdot \mathrm{S}_{\mathrm{f}} \\
\mathrm{E} \cdot \mathrm{N}_{\mathrm{e}} / \mathrm{F} \cdot \mathrm{N}_{\mathrm{f}} \\
\mathrm{E} \cdot \mathrm{Ni}_{\mathrm{e}} / \mathrm{F} \cdot \mathrm{Ni}_{\mathrm{f}} \\
\mathrm{E} \cdot \mathrm{V}_{\mathrm{e}} / \mathrm{F} \cdot \mathrm{V}_{\mathrm{f}}\end{array}$ & $\begin{array}{l}3.5 \\
0.59 \\
54 \\
153 \\
0.83 \\
0.75 \\
0.59 \\
0.51\end{array}$ & $\begin{array}{l}3.4 \\
0.66 \\
\quad 34 \\
54 \\
0.40 \\
0.41 \\
0.18 \\
0.087\end{array}$ & $\begin{array}{l}3.7 \\
0.70 \\
18 \\
17 \\
0.20 \\
0.22 \\
0.045 \\
0.012\end{array}$ & $\begin{array}{l}3.8 \\
0.79 \\
13 \\
12 \\
0.16 \\
0.17 \\
0.025 \\
0.007\end{array}$ & $\begin{array}{l}4.7 \\
0.39 \\
52 \\
110 \\
0.80 \\
0.60 \\
0.41 \\
0.36\end{array}$ & $\begin{array}{l}4.8 \\
0.53 \\
31 \\
95 \\
0.50 \\
0.50 \\
0.15 \\
0.19\end{array}$ & $\begin{array}{l}4.6 \\
0.55 \\
26 \\
\quad 74 \\
0.32 \\
0.35 \\
0.083 \\
0.10\end{array}$ & $\begin{array}{l}4.6 \\
0.66 \\
25 \\
13 \\
0.12 \\
0.15 \\
0.030 \\
0.006\end{array}$ & $\begin{array}{l}3.1 \\
0.64 \\
50 \\
124 \\
0.92 \\
0.69 \\
0.63 \\
0.59\end{array}$ & $\begin{array}{l}2.9 \\
0.66 \\
34 \\
48 \\
0.43 \\
0.36 \\
0.22 \\
0.11\end{array}$ & $\begin{array}{l}3.2 \\
0.87 \\
21 \\
14 \\
0.18 \\
0.18 \\
0.051 \\
0.013\end{array}$ & $\begin{array}{l}3.6 \\
0.98 \\
17 \\
\quad 6 \\
0.11 \\
0.11 \\
0.021 \\
0.003\end{array}$ \\
\hline $\begin{array}{l}A \cdot S_{a} / F \cdot S_{f} \\
A \cdot N_{a} / F \cdot N_{f} \\
A \cdot N_{a} / F \cdot N_{f} \\
A \cdot V_{a} / F \cdot V_{f}\end{array}$ & $\begin{array}{l}0.17 \\
0.25 \\
0.41 \\
0.49\end{array}$ & $\begin{array}{l}0.26 \\
0.44 \\
0.82 \\
0.913\end{array}$ & $\begin{array}{l}0.28 \\
0.58 \\
0.955 \\
0.988\end{array}$ & $\begin{array}{l}0.28 \\
0.62 \\
0.975 \\
0.993\end{array}$ & $\begin{array}{l}0.20 \\
0.40 \\
0.59 \\
0.64\end{array}$ & $\begin{array}{l}0.20 \\
0.46 \\
0.85 \\
0.81\end{array}$ & $\begin{array}{l}0.23 \\
0.48 \\
0.917 \\
0.900\end{array}$ & $\begin{array}{l}0.27 \\
0.60 \\
0.970 \\
0.994\end{array}$ & $\begin{array}{l}0.08 \\
0.31 \\
0.17 \\
0.41\end{array}$ & $\begin{array}{l}0.17 \\
0.25 \\
0.78 \\
0.89\end{array}$ & $\begin{array}{l}0.25 \\
0.42 \\
0.949 \\
0.987\end{array}$ & $\begin{array}{l}0.26 \\
0.46 \\
0.979 \\
0.997\end{array}$ \\
\hline
\end{tabular}

Table 2 Feedstock Properties, Severity Factors and Distribution of S, N, Ni, V (II)

\begin{tabular}{|c|c|c|c|c|c|c|c|c|c|c|c|c|c|}
\hline $\begin{array}{l}\text { Feedstock } \\
\qquad \begin{array}{ll}\mathrm{CCR}_{\mathrm{f}} & (\mathrm{wt} . \%) \\
\mathrm{S}_{\mathrm{f}} & (\text { wt. } \%) \\
\mathrm{N}_{\mathrm{f}} & (\text { wt. } \%) \\
\mathrm{Ni}_{\mathrm{f}} & (\text { wt.ppm) } \\
\mathrm{V}_{\mathrm{f}} & (\text { wt.ppm) }\end{array}\end{array}$ & \multicolumn{4}{|c|}{$\begin{array}{l}\text { Maya } \\
28.8 \\
5.1 \\
0.82 \\
121 \\
649\end{array}$} & \multicolumn{4}{|c|}{$\begin{array}{c}\text { Tia Juana VR } \\
24.6 \\
3.3 \\
0.70 \\
102 \\
763\end{array}$} & \multicolumn{3}{|c|}{$\begin{array}{c}\text { Cerro Negro } \\
20.7 \\
4.3 \\
0.80 \\
120 \\
515\end{array}$} & \multicolumn{2}{|c|}{$\begin{array}{c}\text { Oman VR } \\
17.2 \\
3.7 \\
0.35 \\
24 \\
66\end{array}$} \\
\hline $\begin{array}{l}\mathrm{R} / \mathrm{CCR}_{\mathrm{f}} \\
\mathrm{E} / \mathrm{R}\end{array}$ & $\begin{array}{l}3.48 \\
0.74\end{array}$ & $\begin{array}{l}2.57 \\
0.61\end{array}$ & $\begin{array}{l}2.15 \\
0.52\end{array}$ & $\begin{array}{l}1.83 \\
0.43\end{array}$ & $\begin{array}{l}4.06 \\
0.81\end{array}$ & $\begin{array}{l}2.77 \\
0.66\end{array}$ & $\begin{array}{l}2.30 \\
0.54\end{array}$ & $\begin{array}{l}1.73 \\
0.35\end{array}$ & $\begin{array}{l}4.83 \\
0.81\end{array}$ & $\begin{array}{l}2.88 \\
0.70\end{array}$ & $\begin{array}{l}1.88 \\
0.46\end{array}$ & $\begin{array}{l}2.48 \\
0.62\end{array}$ & $\begin{array}{l}2.13 \\
0.50\end{array}$ \\
\hline $\begin{array}{cc}\mathrm{S}_{\mathrm{e}} \quad(\mathrm{wt} . \%) \\
\mathrm{N}_{\mathrm{e}} \quad(\mathrm{wt} . \%) \\
\mathrm{Ni}_{\mathrm{e}} \quad(\mathrm{wt} \cdot \mathrm{ppm}) \\
\mathrm{V}_{\mathrm{e}} \quad(\mathrm{wt} \cdot \mathrm{ppm}) \\
\mathrm{E} \cdot \mathrm{S}_{\mathrm{e}} / \mathrm{F} \cdot \mathrm{S}_{\mathrm{f}} \\
\mathrm{E} \cdot \mathrm{N}_{\mathrm{e}} / \mathrm{F} \cdot \mathrm{N}_{\mathrm{f}} \\
\mathrm{E} \cdot \mathrm{Ni}_{\mathrm{e}} / \mathrm{F} \cdot \mathrm{Ni}_{\mathrm{f}} \\
\mathrm{E} \cdot \mathrm{V}_{\mathrm{e}} / \mathrm{F} \cdot \mathrm{V}_{\mathrm{f}}\end{array}$ & $\begin{array}{l}4.4 \\
0.50 \\
38 \\
186 \\
0.64 \\
0.46 \\
0.23 \\
0.21\end{array}$ & $\begin{array}{l}4.4 \\
0.55 \\
24 \\
81 \\
0.39 \\
0.31 \\
0.089 \\
0.057\end{array}$ & $\begin{array}{l}4.2 \\
0.50 \\
\quad 18 \\
\quad 48 \\
0.26 \\
0.20 \\
0.045 \\
0.024\end{array}$ & $\begin{array}{l}4.5 \\
0.42 \\
\quad 15 \\
\quad 34 \\
0.20 \\
0.12 \\
0.029 \\
0.012\end{array}$ & $\begin{array}{l}3.0 \\
0.55 \\
39 \\
235 \\
0.75 \\
0.64 \\
0.31 \\
0.25\end{array}$ & $\begin{array}{l}3.1 \\
0.60 \\
24 \\
128 \\
0.43 \\
0.39 \\
0.11 \\
0.075\end{array}$ & $\begin{array}{l}3.2 \\
0.62 \\
17 \\
70 \\
0.30 \\
0.27 \\
0.052 \\
0.028\end{array}$ & $\begin{array}{l}3.3 \\
0.66 \\
11 \\
28 \\
0.15 \\
0.14 \\
0.016 \\
0.005\end{array}$ & $\begin{array}{l}4.1 \\
0.65 \\
65 \\
240 \\
0.66 \\
0.56 \\
0.44 \\
0.38\end{array}$ & $\begin{array}{l}3.9 \\
0.82 \\
64 \\
186 \\
0.32 \\
0.36 \\
0.22 \\
0.15\end{array}$ & $\begin{array}{l}3.9 \\
0.91 \\
23 \\
50 \\
0.14 \\
0.17 \\
0.035 \\
0.017\end{array}$ & $\begin{array}{l}4.4 \\
0.41 \\
5.8 \\
6.6 \\
0.32 \\
0.31 \\
0.063 \\
0.026\end{array}$ & $\begin{array}{l}4.8 \\
0.41 \\
4.8 \\
4.6 \\
0.24 \\
0.21 \\
0.036 \\
0.013\end{array}$ \\
\hline $\begin{array}{l}\mathrm{A} \cdot \mathrm{S}_{\mathrm{a}} / \mathrm{F} \cdot \mathrm{S}_{\mathrm{f}} \\
\mathrm{A} \cdot \mathrm{N}_{\mathrm{a}} / \mathrm{F} \cdot \mathrm{N}_{\mathrm{f}} \\
\mathrm{A} \cdot \mathrm{Ni}_{\mathrm{a}} / \mathrm{F} \cdot \mathrm{Ni}_{\mathrm{f}} \\
\mathrm{A} \cdot \mathrm{V}_{\mathrm{a}} / \mathrm{F} \cdot \mathrm{V}_{\mathrm{f}}\end{array}$ & $\begin{array}{l}0.36 \\
0.54 \\
0.77 \\
0.79\end{array}$ & $\begin{array}{l}0.36 \\
0.62 \\
0.911 \\
0.943\end{array}$ & $\begin{array}{l}0.42 \\
0.65 \\
0.955 \\
0.976\end{array}$ & $\begin{array}{l}0.40 \\
0.67 \\
0.971 \\
0.988\end{array}$ & $\begin{array}{l}0.25 \\
0.36 \\
0.69 \\
0.75\end{array}$ & $\begin{array}{l}0.30 \\
0.58 \\
0.89 \\
0.925\end{array}$ & $\begin{array}{l}0.35 \\
0.64 \\
0.948 \\
0.972\end{array}$ & $\begin{array}{l}0.37 \\
0.69 \\
0.984 \\
0.995\end{array}$ & $\begin{array}{l}0.34 \\
0.44 \\
0.56 \\
0.62\end{array}$ & $\begin{array}{l}0.18 \\
0.38 \\
0.78 \\
0.85\end{array}$ & $\begin{array}{l}0.19 \\
0.52 \\
0.965 \\
0.983\end{array}$ & $\begin{array}{l}0.32 \\
0.38 \\
0.937 \\
0.974\end{array}$ & $\begin{array}{l}0.33 \\
0.46 \\
0.964 \\
0.987\end{array}$ \\
\hline
\end{tabular}

the condensation reaction which condenses the cyclic compounds in the feedstock into the insoluble fraction. This condensation reaction is simultaneous with the thermal cracking reaction.

The correlation was surprisingly high in spite of the wide variety of feedstock properties.

In Figs. 4 and 5, the distribution of nickel and vanadium from the feedstock to the hexane-soluble fraction of the cracking residue was plotted against $\mathrm{R} / \mathrm{CCR}_{\mathrm{f}}$, respectively. It was observed that both $\mathrm{Ni}$ and $\mathrm{V}$ distribution to the hexane-soluble fraction decreased sharply when the value of $R / C_{C A R}$ was less than 3.

Considering that nearly $100 \%$ of the heavy metals are concentrated into the residue of the thermal cracking, this indicates that the selective condensation of the hetero-cyclic compounds with $\mathrm{Ni}$ and
$\mathrm{V}$ into the hexane-insoluble fraction is greatly enhanced when the extent of the thermal cracking reaches a certain level which corresponds to $R /$ $\mathrm{CCR}_{\mathrm{f}}$ value of less than 3 .

In Figs. 6 and 7, the distribution of sulfur from the feedstock to the hexane-soluble (Fig. 5) and insoluble fraction (Fig. 6) of the cracking residue were plotted against $\mathrm{R} / \mathrm{CCR}_{\mathrm{f}}$, respectively. The distribution of sulfur to the hexane-soluble fraction appeared to have fairly high correlation with $R /$ $\mathrm{CCR}_{\mathrm{f}}$ when the value of $\mathrm{R} / \mathrm{CGR}_{\mathrm{f}}$ was less than 3 . As the distribution of sulfur from the feedstock to the thermal cracking residue varies significantly depending on the feedstock, it is interesting to note that those variations are reflected only in the insoluble fraction and not in the soluble fraction of the cracking residue. 


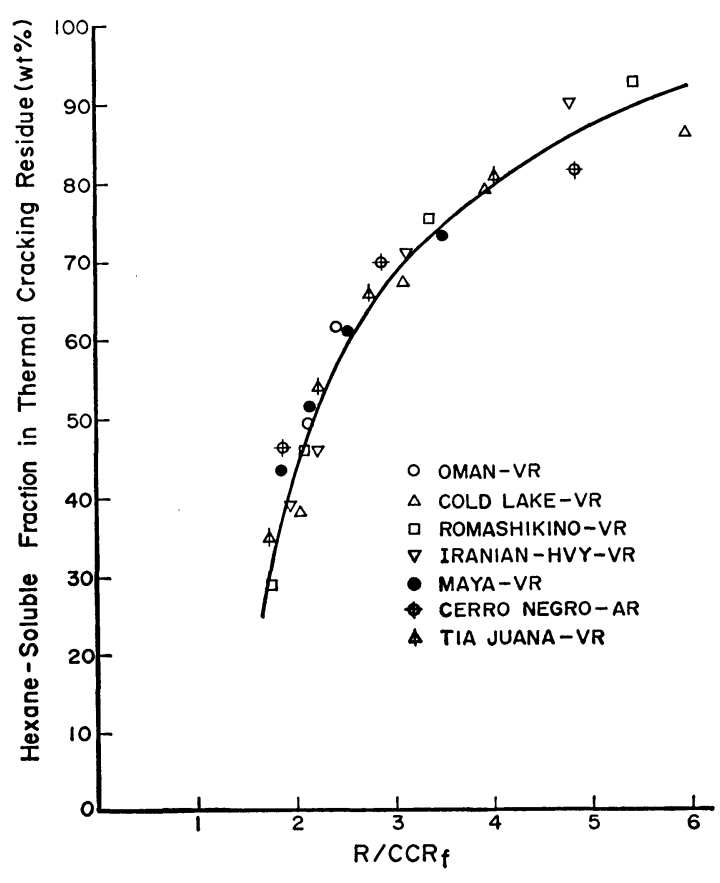

Fig. 3 Hexane-Soluble Fraction in the Cracking Residue vs. $\mathrm{R} / \mathrm{CGR}_{\mathfrak{f}}$

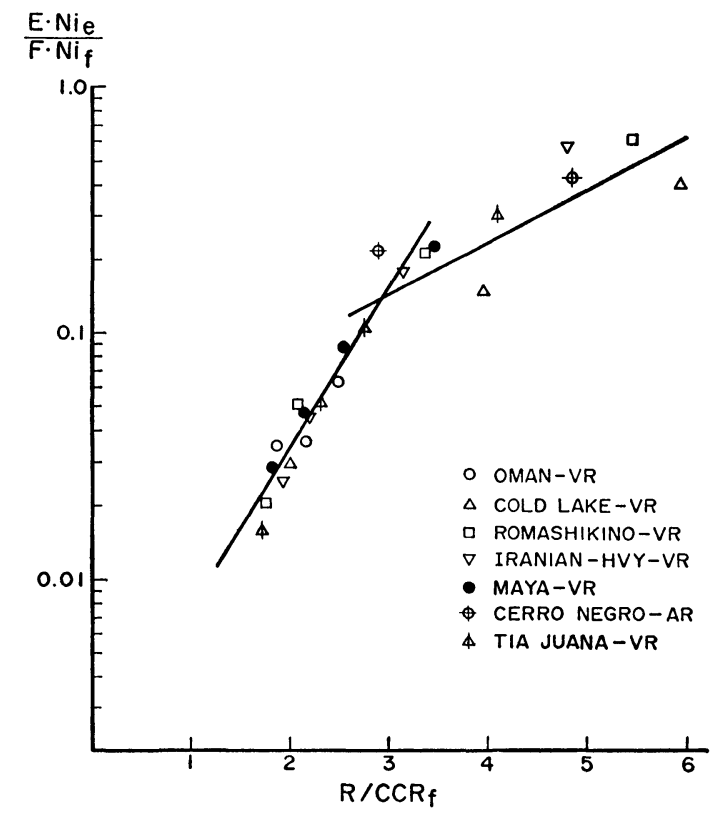

Fig. 4 Distribution of $\mathrm{Ni}$ into Hexane-Soluble Fraction vs. $\mathrm{R} / \mathrm{CGR}_{\mathrm{f}}$

In Figs. 8 and 9, the distribution of nitrogen from the feedstock to the hexane-soluble (Fig. 8) and insoluble fraction (Fig. 9) of the cracking residue were plotted against $\mathrm{R} / \mathrm{CCR}_{\mathrm{f}}$, respectively. A similar tendency as in the sulfur distribution was observed. The correlation between $\mathrm{R} / \mathrm{CCR}_{\mathrm{f}}$ and the nitrogen distribution to the hexane-soluble fraction in the cracking residue appeared fairly high when the value of $R / C_{G C R}$ was less than 3 .

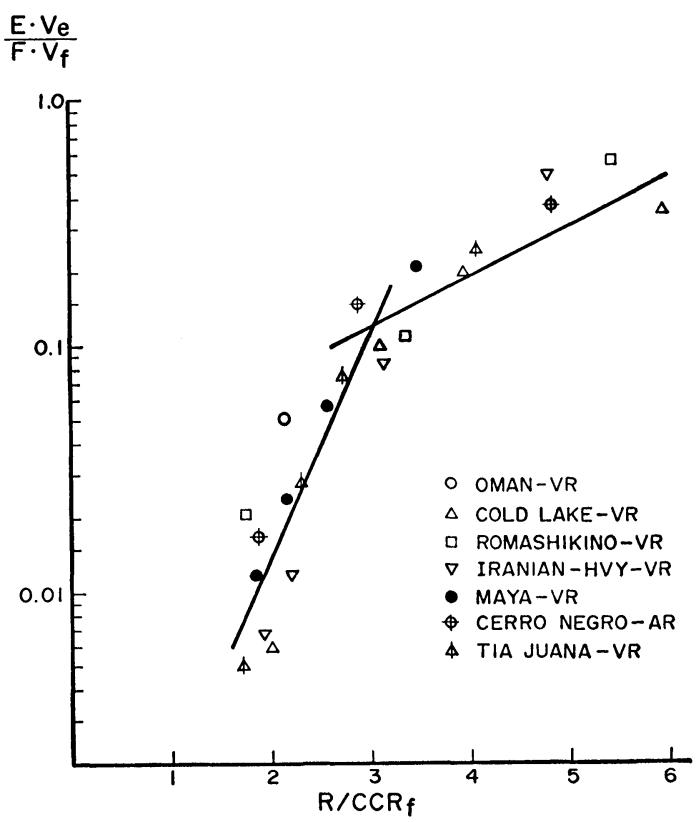

Fig. 5 Distribution of $\mathrm{V}$ into Hexane-soluble Fraction vs. $\mathrm{R} / \mathrm{CCR}_{\mathrm{f}}$

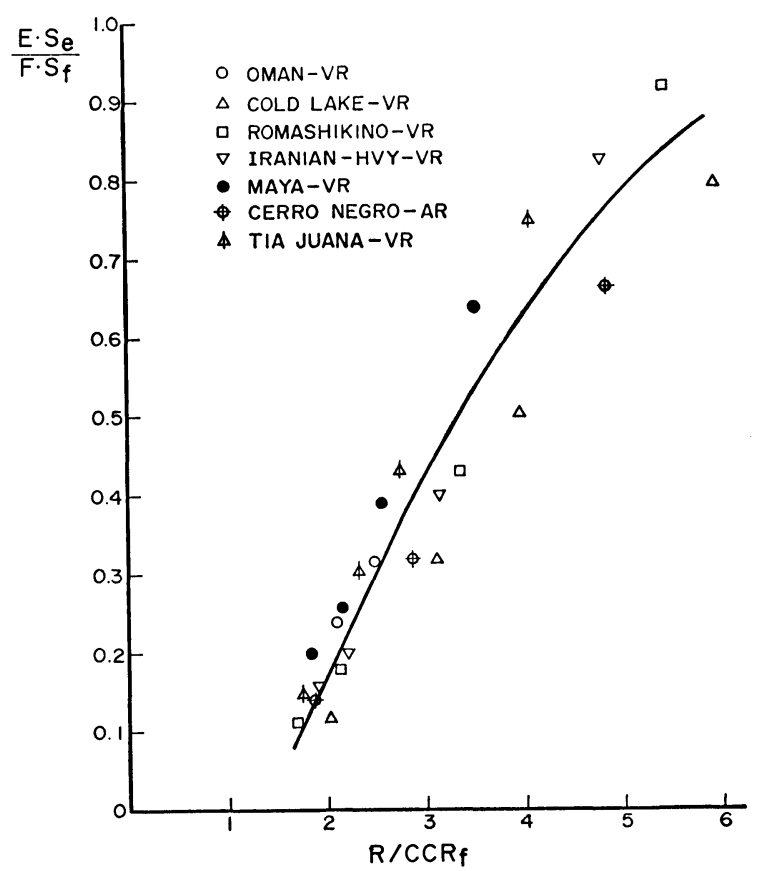

Fig. 6 Distribution of $\mathrm{S}$ into Hexane-Soluble Fraction vs. $R / G R_{f}$

All differences in the feedstock in the distribution of nitrogen to the thermal cracking residue are reflected in the nitrogen distribution to the insoluble fraction and not in the soluble fraction.

Those tendencies for sulfur and nitrogen are also confirmed by Figs. 10 and 11 where the distribution of those compounds in the thermal cracking residue are shown as $A \cdot S_{a} / R \cdot S_{r}$ and $A \cdot N_{a} / R \cdot N_{r}$ in ordinate of the graph versus $R / C G R_{f}$ in abscissa 


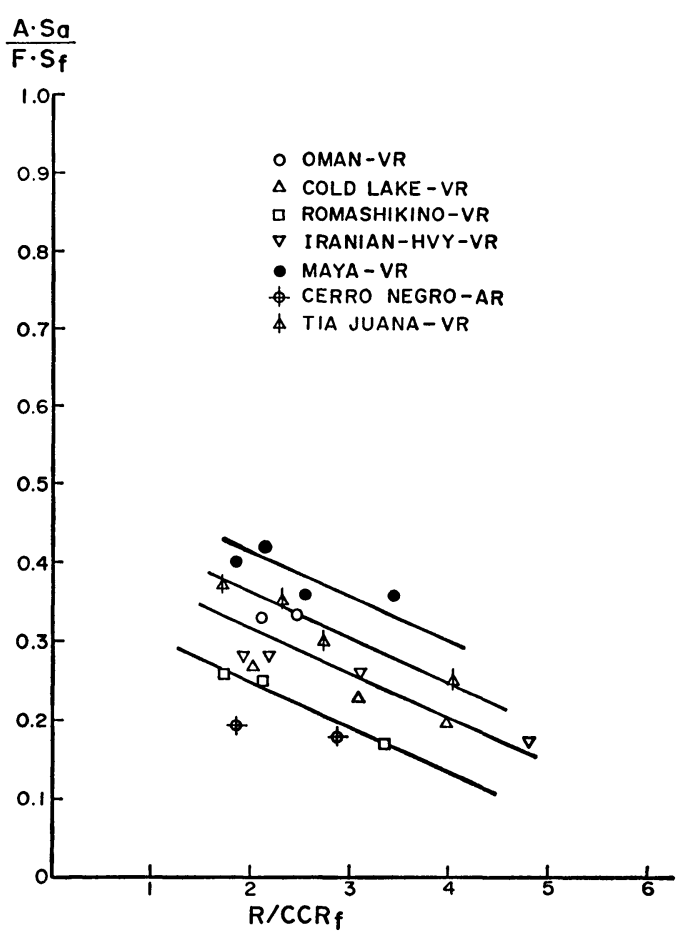

Fig. 7 Distribution of $S$ into Hexane-Insoluble Fraction vs. $\mathrm{R} / \mathrm{CGR}_{\mathrm{f}}$

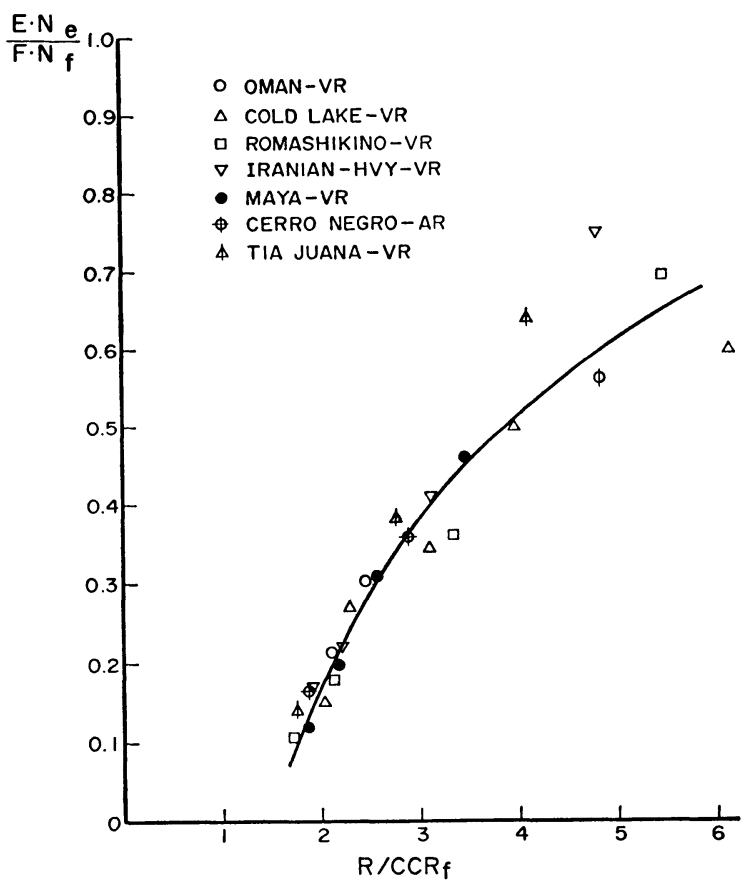

Fig. 8 Distribution of $\mathrm{N}$ into Hexane-Soluble Fraction vs. $R / \mathbf{C C R}_{\mathbf{f}}$

respectively.

From the results obtained, it may be assumed that the selective condensation of the heterocyclic compounds into the hexane-insoluble asphaltenes becomes appreciable only under the thermal cracking severities corresponding to an $\mathrm{R} / \mathrm{CCR}_{\mathrm{f}}$ value

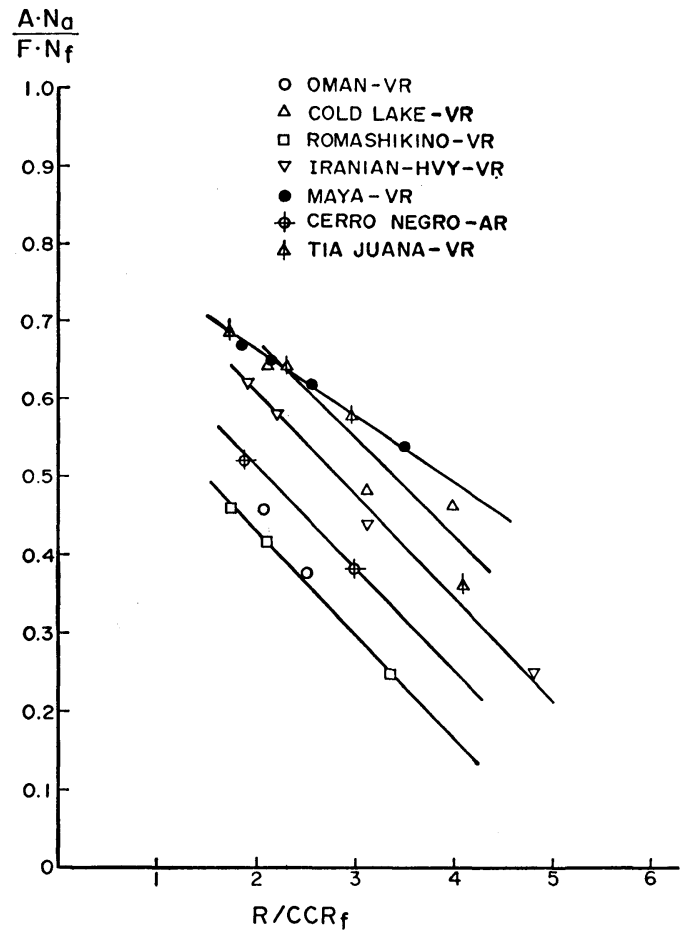

Fig. 9 Distribution of $\mathrm{N}$ into Hexane-Insoluble Fraction vs. $\mathrm{R} / \mathrm{CCR}_{\mathrm{f}}$

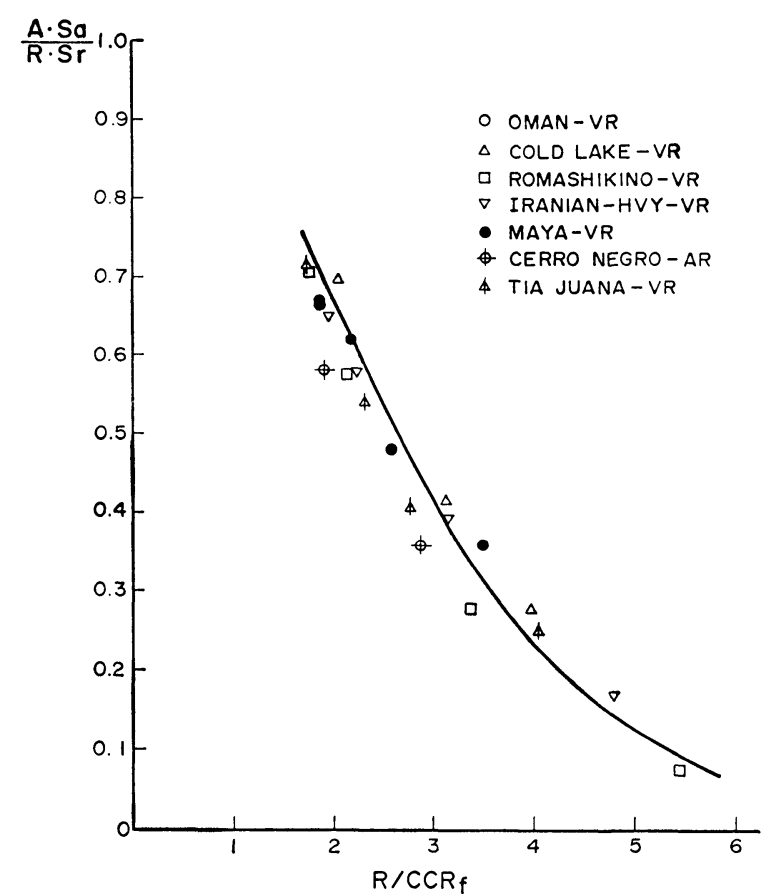

Fig. 10 Distribution of $S$ in the Residue of Thermal Cracking vs. $\mathrm{R} / \mathrm{CCR}_{\mathbf{f}}$

lower than 3.

\section{Conclusions}

In the thermal cracking of various heavy petroleum feedstockes, it was found that the distribution of sulfur, nitrogen, nickel and vanadium from those 


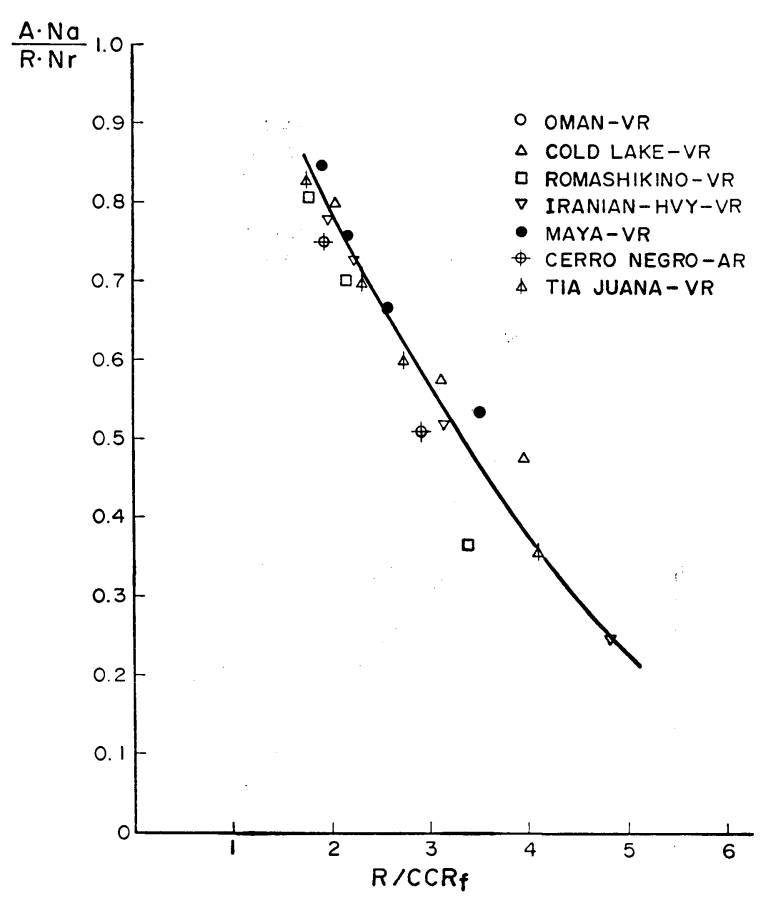

Fig. 11 Distribution of $\mathrm{N}$ in the Residue of Thermal Cracking vs. $\mathrm{R} / \mathrm{CCR}_{\mathrm{f}}$

same feedstocks into the hexane-soluble fraction of the thermal cracking residue showed a high cor- relation with the thermal cracking severity factor, expressed in terms of $\mathrm{R} / \mathrm{CCR}_{\mathrm{f}}$, when the value of $\mathrm{R} / \mathrm{CCR}_{\mathrm{f}}$ was less than 3 .

The selective condensation of nickel and vanadium into the insoluble fraction of the cracking residue became most prominent when the cracking severity of $\mathrm{R} / \mathrm{CCR}_{\mathrm{f}}$ was less than 3 .

The distribution of sulfur and nitrogen were more diversified in the thermal cracking products than that of the heavy metals. However, it was observed that those distributions in the hexane-soluble fraction of the cracking residue were highly correlated with $R / C G R_{f}$ value.

\section{References}

1) Jewell, D. M., Ruberto, R. G., Albaugh, E. W., Query, R. C., Am. Chem. Soc., Div. Petrol. Chem., 20, (4), 743 (1975).

2) Jewell, D. M., Ruberto, R. G., Albaugh, E. W., Query, R. C., I \& EC Fundamentals, 15, (3), 206 (1976).

3) Abu-Elgheit, M., Ijam, M. J., Am. Chem. Soc. Div. Petrol. Chem., 24, (4), 1014 (1979).

4) Raith, J., Lanik, A., Erdoel \& Erdgas, 98, (5), 169 (1982).

5) Yamane, M., Shoji, T., Ozaki, H., Nenryo Kyokaishi, 56, (608), 961 (1977).

6) Yamane, M., PETROTECH, 3, (8), 689 (1980). 


\title{
残油の熱分解における重金属, 硫黄, 窒素の分配に及ぼす熱分解率の影響
}

\author{
菊地 克俊, 大塚 広次, 炁見 弘一 \\ 東洋エンジニアリング(株)，100 千代田区霞ヶ関 3-2-5
}

重金属, 硫黄, 窒素を含有するへテロ環状化合物が, 石油の 重質留分中に多く存在し，更に，この留分を熱分解にかけた場 合には主として熱分解残さ中に濃縮される傾向のあることは既 に報告されている。

本研究報告は, 原料油中に存在するこれら $\mathrm{S}, \mathrm{N}, \mathrm{Ni}, \mathrm{V}$ が 熱分解残さ中のへキサン可溶分と不溶分中にどの様に分配され るかについて, 原料油の種類および熱分解の過酷度との関係に おいて定量的に整理できることを示したものである。

原料油としてはイラニアン・ヘビー, オーマン (中近東), 口 マシキノ (ソ連), マヤ (メキシコ), 七ロ・ネグロ，ティア・ フアナ（ベネゼェラ）およびュールド・レーク・オイルサンド ビチューメン（カナダ）の常圧，あるいは減圧残油を用いた。

熱分解反応は $1,000 \mathrm{ml}$ のオートクレーブを用い, 反応温度 $410^{\circ} \mathrm{C}$, 圧力 118 torr $の 一$ 定条件下で行い, 反応の過酷度 (分解 率）は反応時間を变えることによって広範囲に变劣た。上記の 反応圧力下では反応温度 $410^{\circ} \mathrm{C}$ において沸点 $500^{\circ} \mathrm{C}$ 以下の 油留分が常に蒸発することにより，二次反応を防止している (Fig. 1)。

熱分解残さは $n$-ヘキサンを用いて溶媒分別を行い, 可溶分 と不溶分に分離した。原料油, 熱分解残さおよび残さのへキサ ン可溶分中の $\mathrm{S}, \mathrm{N}, \mathrm{Ni}, \mathrm{V}$ の分析に基づき, これら各元素の
ヘキサン可溶分および不溶分中への分配率を算出した。 異なる原料に対する熱分解過酷度の指標として $\mathrm{R} / \mathrm{CCR}_{\mathrm{f}}$ を 用いた。ここで Rは熱分解残さの原料に対する得率 (wt \%) で あり， $\mathrm{CCR}_{\mathrm{f}}$ は原料中のコンラドソン残炭分 (wt $\%$ ) である。 原料の分析値, $\mathrm{R} / \mathrm{CCR}_{\mathrm{f}}$ の值および各元素の分配率計算値を Tables 1, 2 にまとめて示した。 これらを図によって整理すると以下の結論が得られた。

（1）熱分解残さ油中のへキサン可溶分の含有率は原料の種

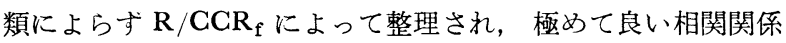
を持っている(Fig. 3)。

（2）原料油から熱分解残さ中のへキサン可溶分への $\mathrm{Ni}, \mathrm{V}$ の分配率は, $\mathrm{R} / \mathrm{CCR}_{\mathrm{f}}$ の值が 3 以下の比較的高い分解率下で原 料油の種類によらず $\mathrm{R} / \mathrm{CCR}_{\mathrm{f}}$ との相関で整理され，しかもこ の領域で急激に減少する(Figs. 4, 5)。即ち, 不溶分への濃縮 がこの領域で顕著となる。

（3）原料油から熱分解残さ中への $\mathrm{S}, \mathrm{N}$ の分配率は原料油 種によってかなり異なるが，この原料油別の差異は残さ中の一 キサン不溶分への分配にのみ反映し，へキサン可溶分への分配 はR $/ \mathrm{CCR}_{\mathrm{f}}$ の值が 3 以下の領域では $\mathrm{R} / \mathrm{CCR}_{\mathrm{f}}$ のみによって決 まる(Figs. 6 11)。

\section{Keywords}

CCR, Heavy metal, Nitrogen, Residual oil, Sulfur, Thermal cracking 